\title{
Tree-Related Microhabitats Follow Similar Patterns but are More Diverse in Primary Compared to Managed Temperate Mountain Forests
}

\author{
Thomas Asbeck, ${ }^{1 *} \odot$ Daniel Kozák, ${ }^{2}$ Andreea P. Spînu, ${ }^{1}$ Martin Mikoláš, ${ }^{2}$ \\ Veronika Zemlerová, ${ }^{2}$ and Miroslav Svoboda ${ }^{2}$
}

\begin{abstract}
${ }^{1}$ Chair of Silviculture, University of Freiburg, Tennenbacherstr. 4, 79085 Freiburg, Germany; ${ }^{2}$ Department of Forest Ecology, Faculty of Forestry and Wood Sciences, Czech University of Life Sciences Prague, Kamýcká 129, 16521 Prague, Czech Republic
\end{abstract}

\begin{abstract}
The impact of forest management on biodiversity is difficult to scrutinize along gradients of management. A step towards analyzing the impact of forest management on biodiversity is comparisons between managed and primary forests. The standardized typology of tree-related microhabitats (TreMs) is a multi-taxon indicator used to quantify forest biodiversity. We aim to analyze the influence of environmental factors on the occurrence of groups of TreMs by comparing primary and managed forests. We collected data for the managed forests in the Black Forest (Germany) and for the primary forests in the Western (Slovakia) and Southern Carpathians (Romania). To model the richness and the different groups of TreMs per tree, we used generalized linear mixed models with diameter at breast height (DBH), altitude, slope and aspect as predictors for European beech (Fagus sylvatica (L.)), Norway spruce (Picea abies (L.)) and sil-
\end{abstract}

Received 14 September 2020; accepted 2 July 2021;

published online 11 August 2021

Supplementary Information: The online version contains supplementary material available at https://doi.org/10.1007/s10021-021-0068 $1-1$.

Author Contributions T.A. performed the research, analyzed the data and wrote the paper; D.K., M.S. performed the research and wrote the paper; A.S., M.M. and V.S. contributed to writing the paper.

*Corresponding author; e-mail: Thomas.asbeck@waldbau.uni-freiburg.de ver fir (Abies alba (Mill.)) in primary and managed temperate mountain forests. We found congruent results for overall richness and the vast majority of TreM groups. Trees in primary forests hosted a greater richness of all and specific types of TreMs than individuals in managed forests. The main drivers of TreMs are DBH and altitude, while slope and aspect play a minor role. We recommend forest and nature conservation managers to focus: 1) on the conservation of remaining primary forests and 2) approaches of biodiversity-oriented forest management on the selection of high-quality habitat trees that already provide a high number of TreMs in managed forests based on the comparison with primary forests.

Key words: integrative conservation approaches; old-growth elements; natural disturbances and dynamics; black Forest; carpathians; habitat trees.

\section{HighLights}

- Primary forests provide more tree-related microhabitats than managed ones 
- The conservation of primary forests is essential for providing tree microhabitats

- Selecting habitat trees that provide microhabitats is crucial in managed forests

\section{INTRODUCTION}

To tackle the biodiversity and the climate crisis that forests face (Schelhaas and others 2003; Hanewinkel and others 2013; Seidl and others 2014, 2017), a great number of approaches including adaptive strategies, retention forestry, close-to-nature forest management or ecological forestry have been developed (Bauhus and others 2009; Messier and others 2019; Gustafsson and others 2020; Čada and others 2020). Yet, the impact of altered management approaches on biodiversity is difficult to scrutinize on large spatial scales as well as along gradients of management (Paillet and others 2010; Bruelheide and others 2020; Asbeck and others $202 \mathrm{lb}$ ). One major step towards analyzing the impact of management on biodiversity is comparisons between types of managed and unmanaged forests, including sites where management has ceased relatively recently and to a lesser extent primary forests (Paillet and others 2010; Schall and others 2018). However, when it comes to summarizing the margins of influence of management on biodiversity, the results may vary greatly according to the time of absence or type of management (Paillet and others 2015b; Schall and others 2020). Therefore, remnants of primary forests deliver a unique source of information to address the question of influence of management or natural disturbances and dynamics on biodiversity (Kozák and others 2018); however, these remnants are rare and difficult to locate (Sabatini and others 2018; Mikoláš and others 2019). Another challenge in assessing differences between managed and primary forests is the comparability of datasets; for instance, the collection of data on taxonomic groups might not always be comparable across sites (Bruelheide and others 2020). To overcome this problem partially, a multi-taxon indicator beyond single-species information has been widely implemented and used for quantifying forest biodiversity, namely the standardized, hierarchical typology of tree-related microhabitats(Larrieu and others 2012, 2018; Paillet and others 2018; Asbeck and others 2020b; Basile and others 2020a; Jahed and others 2020; Asbeck and others 2021a). The most common definition for a tree-related microhabitat (TreM) is "a distinct, well delineated structure occurring on living or standing dead trees, that constitutes a particular and essential substrate or life site for species or species communities during at least a part of their life cycle to develop, feed, shelter or breed" (Larrieu and others 2018). The hierarchical TreM typology distinguishes 15 groups of TreMs in seven forms:

- Cavities: woodpecker breeding cavities, rot holes, concavities, insect galleries and bore holes;

- Tree injuries and exposed wood: exposed sapwood and/or exposed heartwood;

- Crown deadwood in different forms;

- Excrescences: twig tangles (witches broom), cankers and burrs;

- Fruiting bodies of saproxylic fungi and slime molds: perennial and ephemeral fungi fruiting bodies;

- Epiphytic, epixylic and parasitic structures: epiphytic crypto- and phanerogams, nests of vertebrates and invertebrates, microsoils

- Fresh exudates such as sap run and heavy resinosis.

A variety of taxonomic groups have been linked to the different levels of the hierarchical typology of TreMs based on literature and empirical data and include invertebrates such as insects, arachnids and gastropods as well as vertebrates such as birds, rodents and bats (Larrieu and others 2018; Paillet and others 2018; Basile and others 2020a).

Based on this standardized typology, datasets from primary (Kozák and others 2018) as well as managed forests (Asbeck and others 2019) provided first analyses of driving factors of TreM richness in temperate mountain forests of Europe. The identification of these drivers of TreM abundance and richness still deserves further attention as most studies have only been able to identify that DBH and tree species are most important for living trees (Larrieu and Cabanettes 2012; Paillet and others 2019; Asbeck and others 202la). Other studies have analyzed the influence of the living status, ownership or the time since last harvest on TreMs(Larrieu and others 2012; Johann and Schaich 2016; Paillet and others 2017, 2019). As TreMs are considered a biodiversity indicator that could guide the selection of retention elements in managed forests, one major open question is the impact of management and the natural life cycle of trees in primary forests on the richness of TreMs (Larrieu and others 2012, 2014; Asbeck and others 2020b). Here, we aim to disentangle the influence of environmental factors on the richness and occurrence of specific groups of TreMs by directly comparing primary and managed forests. This might provide valuable information for the devel- 
opment of evidence-based management strategies to provide old-growth elements and small-scale retention elements throughout managed forests and as well address the importance of primary forests for the conservation of biodiversity (Bauhus and others 2009; Asbeck and others 2020b; Basile and others 2020a; Gustafsson and others 2020). Old-growth elements are largely absent in managed forests, but provide valuable and rare habitats for the conservation of dependent species and increase the connectivity and dispersal ability of these species (Baguette and others 2013; Kraus and Krumm 2013). We aim to provide a first comparison of drivers of TreM richness between primary and managed forests that 1) highlights the importance of the primary forests for the conservation of biodiversity and 2) identifies focal points for forest management to increase these habitats for the conservation of forest dwelling species.

\section{Material ANd Methods}

\section{Data Collection}

In total, for both the managed $(N=3327)$ and primary forests $(N=14,665)$ we recorded TreM data for 17,992 trees in European temperate mountain forests. We collected data for the managed forests placed in one-hectare forest plots located on state land in the Black Forest region (latitude: $47.6^{\circ}-48.3^{\circ} \mathrm{N}$, longitude: $7.7^{\circ}-8.6^{\circ} \mathrm{E}$, WGS 84, Figure 1). The plot selection followed a landscape gradient of forest cover in the $25 \mathrm{~km}^{2}$ surrounding the plots and a gradient of structural complexity indicated by the number of standing dead trees per plot $(0,1-9,>9$ snags per ha); all trees are located in stands older than 60 years and exclude any infrastructure (for details, see Storch and others 2020). We inventoried 161 plots of 1 ha size, where a full inventory of all living trees and their TreMs would have been beyond the capacity of this project. Hence we pre-selected living trees based on their crown radius from GIS in four classes $\left(<31 \mathrm{~m}^{2},>31 \mathrm{~m}^{2}\right.$ and $<51 \mathrm{~m}^{2},>51 \mathrm{~m}^{2}$ and $<97 \mathrm{~m}^{2},>97 \mathrm{~m}^{2}$ ) and inventoried two trees in each of the three lower classes and 15 trees in the largest class per plot. We automatically delineated individual tree crowns of all trees in all plots using the TreeVis software (Weinacker and others 2004). The data basis was a digital surface model (DSM) photogrammetrically generated from aerial images (40 cm ground sampling distance) and a digital terrain model (DTM) based on LIDAR flights. We selected a subset of plots that were managed for timber production and excluded strict- protected ones reported in Asbeck and others 2019. The plots are in continuous cover forests excluding clear-felling and employing the principles of closeto-nature forest management (CTNFM). Close-tonature forest management in the Black Forest is characterized by common principles including: a) use of site-adapted tree species, typically of the natural forest vegetation, b) promotion of mixed and structurally diverse forests, c) avoidance of large canopy openings such as clear-cuts, d) employment of natural processes such as natural regeneration, self-thinning and self-pruning, and (e) silvicultural focus on individual trees rather than stands (Bauhus and others 2013; Brang and others 2014). We recorded the position of all inventoried trees, their diameter at breast height (DBH), species identity and TreMs in the snow-free and leaf-free period between fall 2016 and spring 2017. We collected all data, including altitude per tree with the use of handheld tablets.

For the primary forests, we collected the data in mixed forests of Western (Slovakia, 210 plots) and Southern Carpathians (Romania, 190 plots). We refer to "primary forest" as a forest developed under a natural disturbance regime that showed little or no evidence of past human activities. Our definition of primary forests is consistent with relatively widely accepted criteria for European oldgrowth forests (Wirth and others 2009; Burrascano and others 2013; Knorn and others 2013). However, in addition to late-successional forests, we also considered all developmental phases, including early seral stages and young forests that originated after natural disturbances and natural regeneration, and without subsequent management, as with primary forest mosaics (Mikoláš and others 2019). The main criteria of the primary forest inclusion were the absence of the historical human impact detected by the forest stand maps, historical maps and field inventory. During the field inventory, all forests were surveyed for various indicators of naturalness (for example, coarse woody debris in various stages of decay, pit-and-mound topography, large trees, natural tree species composition). Surveyed plots were selected from an existing international network of permanent inventory plots (REMOTE, Www.remoteforests.org), encompassing primary forests in central and Eastern Europe. All data were collected within 0.15 ha circular plots randomly distributed across various environmental gradients (but see Kozák and others, 2018 for details of plot selection). Across the primary forest plots, we recorded the positions of all living, adult trees ( $\geq 6 \mathrm{~cm} \mathrm{DBH})$, their $\mathrm{DBH}$, species identity and TreM profile based on methodology by 


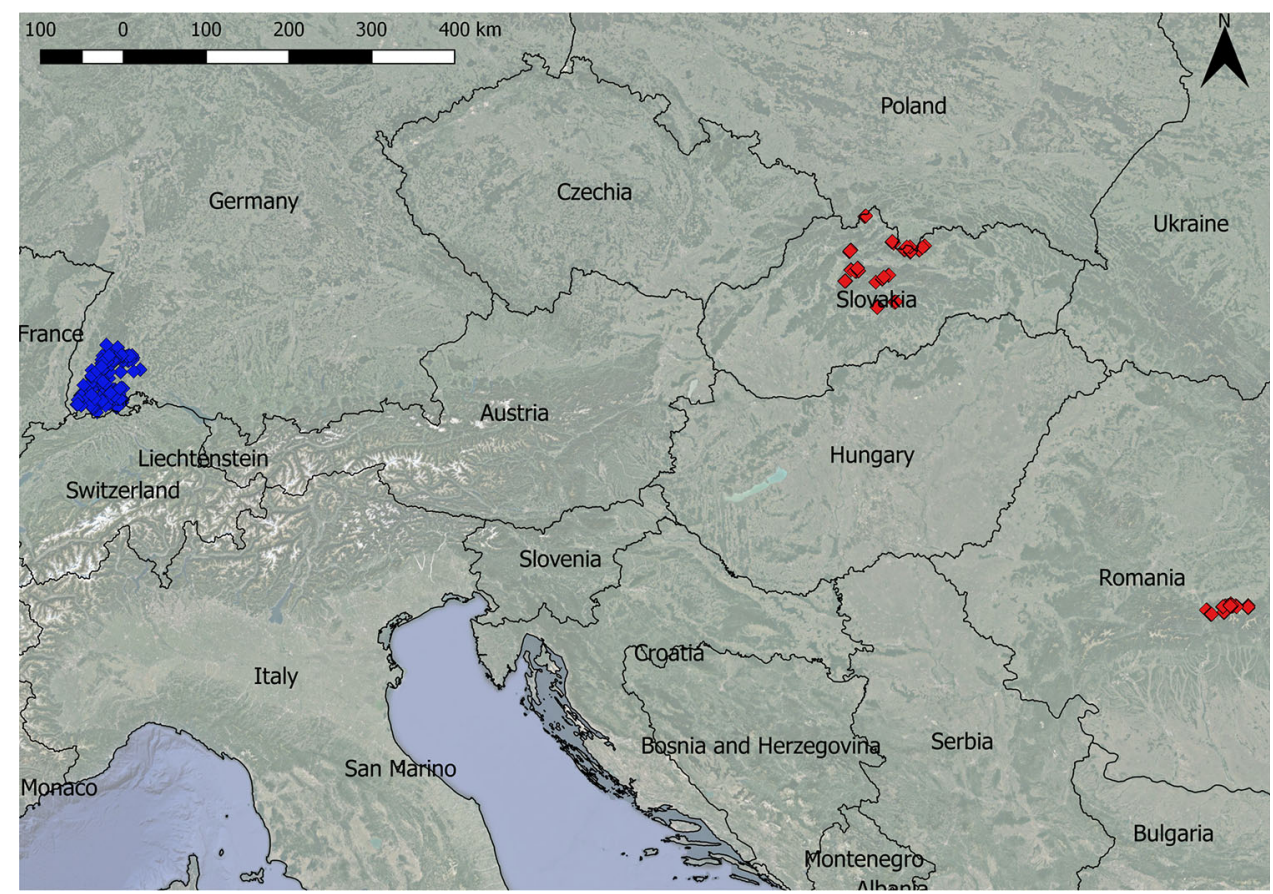

Figure 1. Map of the research area, indicating the location of the study sites in the primary forests (red squares) in Slovakian and Romanian Carpathians and in the managed forests (blue squares) in the Black Forest, Germany.

Larrieu and others (2018) during the vegetation season in 2018 and 2019. Altitude was measured at the center of the plot.

To decrease the observer effect (Paillet and others 2015a), inventories were carried out by the same team within each location. Three observers in the Black Forest and two in the Carpathian region visually inspected the TreMs following the same hierarchical typology (Larrieu and others 2018).

\section{Statistical Analyses}

In our analyses, we focused on a comparison of living trees, since data for dead trees were not available for the Black Forest and, as from a management perspective, the selection of high quality living habitat trees is more complex than of standing dead trees (Asbeck and others 2020b). We calculated the overall richness as the sum of different TreM groups per living tree. To model the richness as well as the groups of TreMs per living tree, we used generalized linear mixed models (GLMMs) as the number of TreMs per tree is count data and to account for spatial autocorrelation between the plots, similar as in many previous studies (Paillet and others 2015a, 2018, 2019; Asbeck and others 2020a).

We tested the effects of the DBH, altitude, slope and aspect on the richness and groups of TreMs on individual living European beech (Fagus sylvatica
(L.)), Norway spruce (Picea abies (L.)) and silver fir (Abies alba (Mill.)) trees for managed and primary forests. These predictors have previously shown to drive the richness and number of groups of TreMs per tree (Larrieu and Cabanettes 2012; Kozák and others 2018; Asbeck and others 2019, 2021a; Paillet and others 2019). We used the average slope of the plot, and aspect was expressed as northness according to the formula: northness $=$ cosine [(aspect in degrees $* \pi$ )/180)], similar as done earlier (Janda 2019). Northness will take values close to 1 if the aspect is generally northward and close to -1 if the aspect is southward. We did not include interactions in the models to prevent over-parameterization, and since in previous studies, these predictors were less significant than the single predictors (Asbeck and others 2019; Paillet and others 2019). Prior to running the models, we checked the predictors for correlations according to a standardized procedure (Zuur and others 2010, SI Table Al). We adjusted the continuous predictors due to the different scales using the default setting of the scale function in $\mathrm{R}$, which calculates the mean and the standard deviation (sd) of the predictor and then scales each element by those values by subtraction of the mean and dividing by the sd.

The full models for European beech, Norway spruce and silver fir in managed and primary 
temperate mountain forests consisted of these predictors:

$\mathrm{DBH}+$ altitude + slope + aspect $+($ llPlotID $)$

To prevent autocorrelation of trees within the same plot that might have more similar characteristics than individuals in different plots (Dormann 2013), we included plot identity as random factor. The computation of models was performed in R (R Core Team 2016). Since the richness data for TreMs were of count type, we built models with the "glmmTMB function" of the "glmmTMB package" (Brooks and others 2017) with a negative binominal distribution to solve overdispersion. To test for under- and overdispersion as well as zero inflation in the models, we used the "DHARMa package" (Hartig 2018). Obviously, with a large number of living trees that do not bear TreMs, there were signs of zero inflation; however, models did not improve when considering this. We used the "ggpredict" function of the ggeffects package for plotting, which sets all other predictors, except the one for which the effect is shown, to the same value (Lüdecke 2018).

\section{RESUlts}

\section{Raw Inventory Data at Tree Level in Managed and Primary Forests}

We restricted the analyses to living individuals of the three main tree species that were Norway spruce, European beech and silver fir in both data sets. Across all three species, the individuals in the primary forests provided a greater richness of TreMs per living tree compared to the managed temperate mountain forests (Table 1, Figures 2, 3 and 4).

\section{Results of the Statistical Analyses}

We found congruent results for TreM richness and among the majority of TreM groups across the studied forests. In the vast majority of models, trees in primary forests provided higher levels of TreMs (Figures 2, 3 and 4). The only case where managed forests seem to provide a significantly greater number of TreMs is crown deadwood in European beech (Figure 2). The most important predictor for overall TreM richness and most groups of TreMs is the DBH of the trees (Table 2, Figures 2, 3 and 4). Altitude as a proxy of the site conditions was an important driving factor for TreM richness in beech (Figure 2), rot holes in beech and fir (Figure 2 and 4) as well as for epiphytes in spruce and fir (Figures 3 and 4; Table 2). All groups increased significantly with increasing $\mathrm{DBH}$ as well as with increasing altitude apart from rot holes in fir (Ta- ble 2). Crown deadwood in fir increased with increasing slope (Figure 4 and Table 2), while aspect was only significant for concavities in spruce that increased on more northern slopes (Figure 3 and Table 2).

We found significant predictors in 71 of the total 96 models in both primary and managed forests (Table 2, Figure Al). In 17 cases, only the TreMs in primary forests were significantly related to one or a combination of the tested predictors. Insect galleries in all tree species (Table 2, Figure Al) were, for instance, only related to predictors in the primary forests. In contrast, we found the opposite pattern that TreMs are significantly predicted in managed but not in primary forests only two times, for nests in Norway spruce that increase significantly with increasing DBH and slope in managed forests (Table 2). In several cases, low number of observations omitted the statistical analyses, for instance for perennial and annual fungi in managed forests (Table A2).

\section{Discussion}

The increasing importance of primary forests as key habitats for the conservation of biodiversity recently inspired silvicultural approaches that emphasize the role of old-growth attributes and natural disturbance legacies in management activities (Keeton 2006; Lindenmayer and others 2006; Bauhus and others 2009; Nagel and others 2014; Thom and others 2019; Čada and others 2020). Our approach compared the tree-level TreM richness of primary forests in the Carpathians with managed forests in the Black Forest to analyze the role of environmental factors on the provisioning of specific habitats. Trees in primary temperate mountain forests hosted a more diverse array of TreMs in terms of overall richness and specific types of TreMs compared to their counterparts in managed forests.

The most prominent result is that we observed similar patterns but higher numbers of TreMs on living trees located in primary compared to those in managed temperate mountain forests. Previous studies were not able to extract this information as clearly as we did; for instance, Vuidot and others (2011) did not find this difference when comparing managed and unmanaged forests on the tree level. Our findings might be influenced by the time that management is absent as in the mentioned study the unmanaged forests were left without timber extraction for a maximum of 150 years and logged previously. Regarding the natural life cycle of the inventoried tree species, the time span of 150 years 
Table 1. Comparison of the Main Attributes of the Inventoried Living Trees and Sites in the Inventoried Managed and Primary Forests.

\begin{tabular}{|c|c|c|c|c|c|c|c|c|c|}
\hline \multirow[t]{2}{*}{ Tree species } & \multirow{2}{*}{$\begin{array}{l}\mathrm{N} \text { of } \\
\text { trees }\end{array}$} & \multirow{2}{*}{$\begin{array}{l}\text { Share } \\
(\%)\end{array}$} & \multicolumn{3}{|c|}{$\mathrm{DBH}(\mathrm{cm})$} & \multicolumn{2}{|l|}{ Mean (SD) } & \multirow{2}{*}{$\begin{array}{l}\text { Aspect } \\
\text { (northness) }\end{array}$} & \multirow{2}{*}{$\begin{array}{l}\text { TreM richness/ } \\
\text { living tree }\end{array}$} \\
\hline & & & Min & Max & Mean (SD) & Altitude (m) & Slope $\left({ }^{\circ}\right)$ & & \\
\hline \multicolumn{10}{|l|}{ Managed forests } \\
\hline European beech & 877 & 26.4 & 7 & 128 & $36(21)$ & $750(202)$ & $20.0(7.7)$ & $-0.2(0.6)$ & $1.9(1.1)$ \\
\hline Norway spruce & 1788 & 53.7 & 7.5 & 115 & $46.5(15)$ & $910(178)$ & $11.2(7.9)$ & $0.2(0.7)$ & $1.6(0.7)$ \\
\hline Silver fir & 662 & 19.9 & 8 & 137 & $56(20)$ & $849(140)$ & $13.9(9.3)$ & $0.2(0.7)$ & $1.9(0.9)$ \\
\hline $\begin{array}{l}\text { Total } \\
\text { Primary forests }\end{array}$ & 3327 & & & & $46(19)$ & $856(190)$ & $14.1(8.9)$ & $0.1(0.7)$ & $1.7(0.9)$ \\
\hline European beech & 3938 & 26.9 & 6 & 129 & $36(22)$ & $1132(112)$ & $31.4(6.2)$ & $0.03(0.7)$ & $3.2(1.5)$ \\
\hline Norway spruce & 9457 & 64.5 & 6 & 117 & $35(17)$ & $1442(134)$ & $32.8(8.8)$ & $0.3(0.6)$ & $3.0(1.0)$ \\
\hline Silver fir & 1270 & 8.7 & 6 & 119 & $32(24)$ & $1154(134)$ & $33.4(6.0)$ & $-0.01(0.5)$ & $2.8(1.2)$ \\
\hline Total & 14,665 & & & & $35(19)$ & 1334 (194) & $32.4(8.0)$ & $0.18(0.6)$ & $3.0(1.2)$ \\
\hline
\end{tabular}

might be too limited to find significant differences in TreMs, as tree age of the individuals in the inventoried primary forests can reach more than 300 years (Spînu and others 2020). In contrast, we are the first to analyze primary plots without any traces of human activities due to difficulty of accessibility in temperate forests, for boreal systems first results show that old-growth patches provide a higher number and diversity of TreMs (Martin and others 2021). Despite the fact that CTNFM aims at multi-functionality and incorporates other functions than merely timber production, it creates relatively uniform structures and productive stands with limited longevity of the trees (Storch and others 2018; Frey and others 2020; Asbeck and Frey 2021). On the other hand, trees in primary forests often grow slowly, competing with other individuals under the vertically diverse canopy with longevity multiple times higher than the trees in managed stands (Bigler and Veblen 2009; Di Filippo and others 2012). Suboptimal tree growing conditions, such as poor soil conditions or suppression, were connected to the formation of certain TreMs, such as cracks, bark lesions and rot holes (Jönsson 2000; Fritz and Heilmann-Clausen 2010). Such conditions are more likely to be found in primary forests because forest management is often avoided on nutrient poor and inaccessible sites. In addition, suppressed trees are removed to some extent in CTNFM, whenever they compete strongly with high-quality trees for timber production. In this context, tree senescence is considered to play an important role for the occurrence of TreMs, but so far has only been modeled in one cross-sectional (Courbaud and others 2017) and one empirical study (Puverel and others 2019). We assume that the abundance and richness of TreMs increase with tree senescence, which might be the main reason for trees in primary forests bearing more TreMs, as they could be older compared to individuals of similar dimensions in managed forests.

Increased richness of specific TreM types such as rot holes, concavities or crown deadwood on primary forest trees implies the importance of the natural disturbances for the formation of certain TreMs. The most important natural disturbances in central and eastern European mountain forests are wind, bark beetle outbreaks, snow and ice (Nagel and others 2014; Svoboda and others 2014; Janda and others 2017; Kulakowski and others 2017). The importance of effects from large-scale cyclones and convective instabilities on dynamics of these mountain forests has recently been recognized (Pettit and others 2021). Wind can cause damage either directly by breaking the stem or limb of a tree or indirectly through trees damaging each other when breaking or uprooting. Forest management may substitute the role of wind as damage caused during felling operations could create similar TreMs (Vuidot and others 2011). Such practices may be effective in mimicking the natural creation of TreMs in managed stands (Fritz and HeilmannClausen 2010). Besides wind damage, galleries from wood drilling insects resulting from insect outbreaks of various severities are common in primary forests, but not significantly related to any of the predictors in managed forests. Here, we cannot fully distinguish whether the lack of significance is directly related to management or if it is due to the lower number of observations in managed forests. We cannot distinguish these effects from our models, but assume that this effect might be a direct consequence of the removal of trees showing insect galleries. Clearly, this group of TreMs is highly unfavorable in managed forests because of its negative impact on timber value combined with 
(a) TreM richness

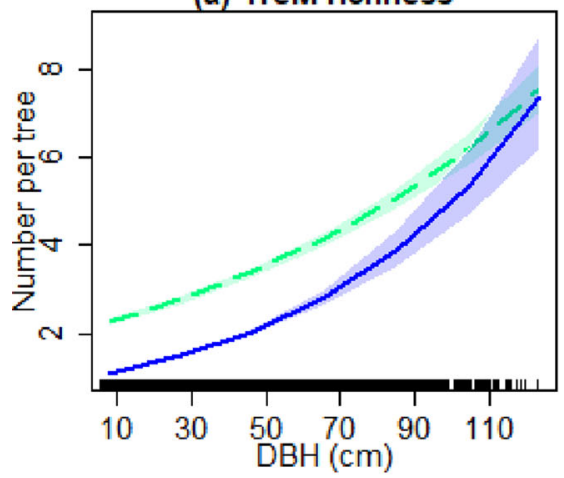

(a) Concavities

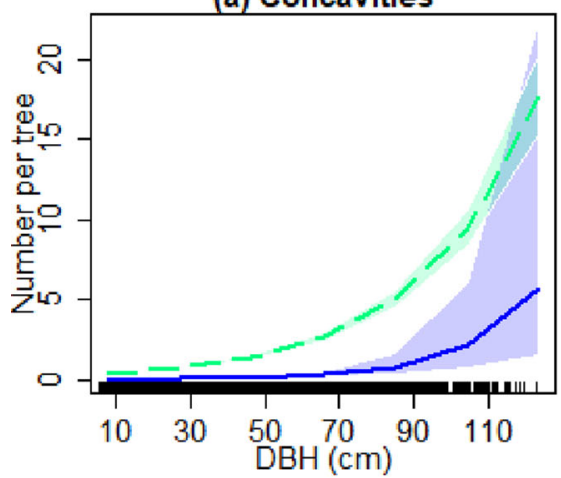

(a) Crown deadwood

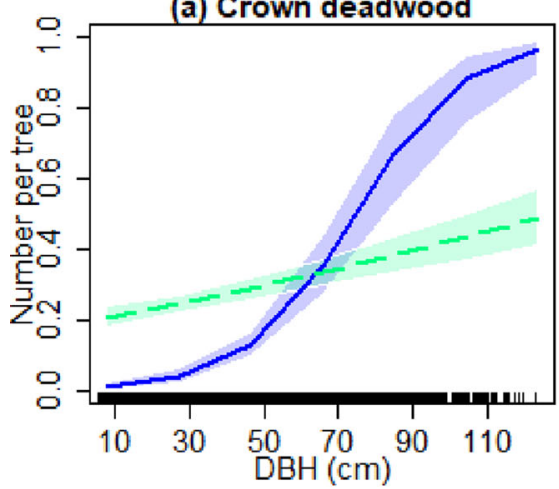

(b) TreM richness

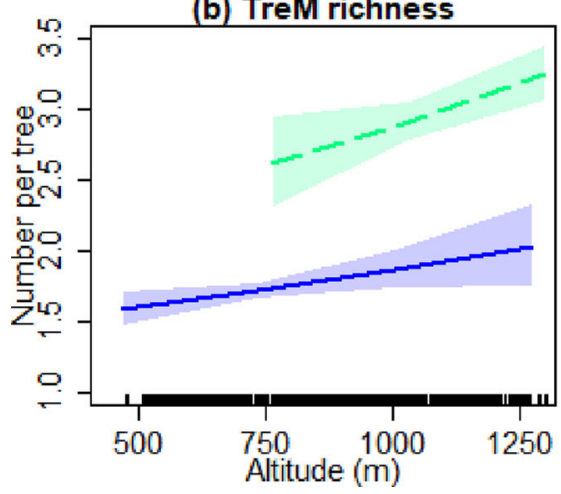

(a) Woodpecker cavities

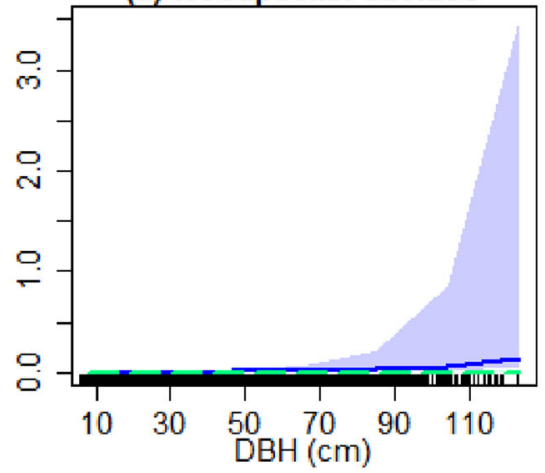

(a) Exposed sapwood

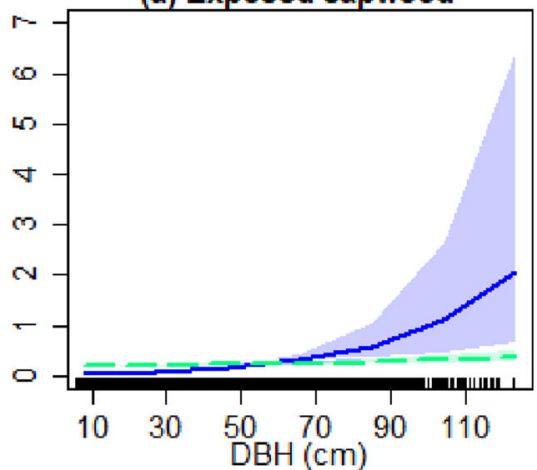

(a) Epiphytes

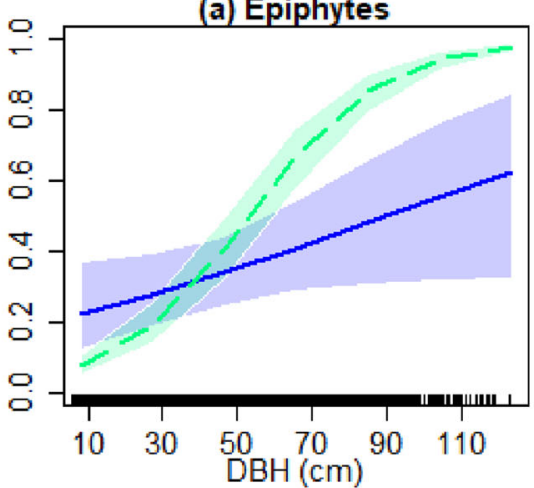

(b) Rot holes

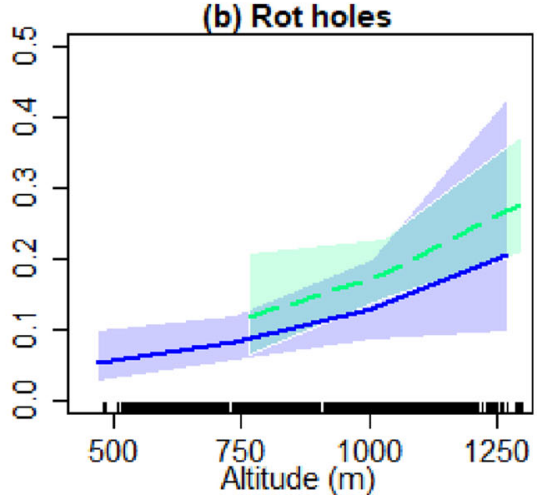

(a) Rot holes

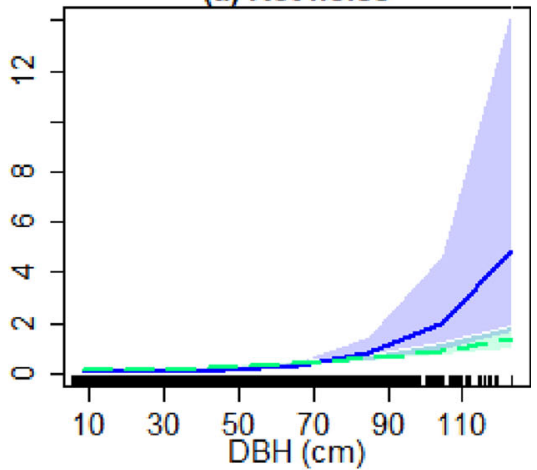

(a) Exposed sap/heartwood

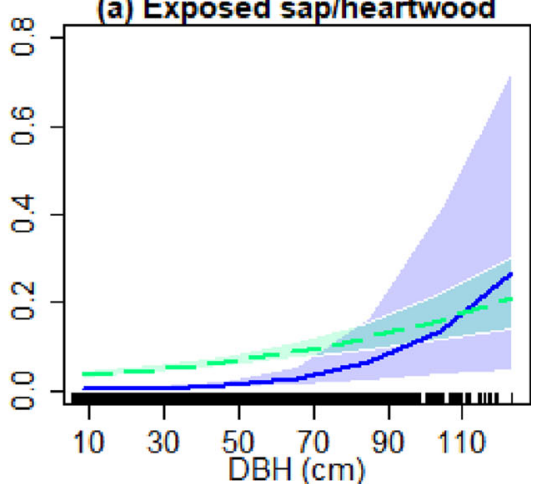

(a) Microsoils

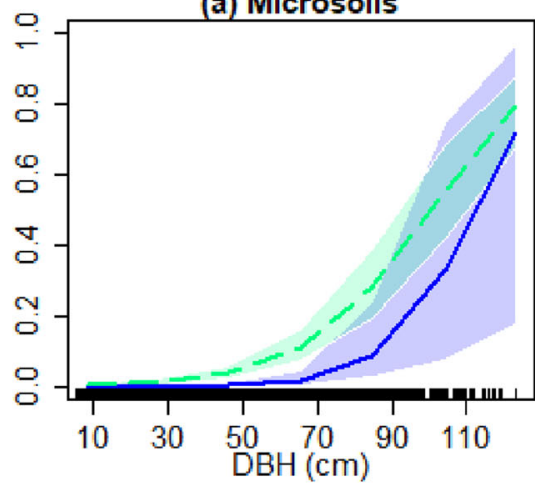

\section{European beech}

- - - Primary forests Managed forests

Figure 2. Effect plots of the significant influence of $\mathbf{a} \mathrm{DBH}$ and $\mathbf{b}$ altitude for overall TreM richness and groups per tree from the generalized linear mixed models of European beech in managed (blue) compared to primary (green) forest sites. The light color bands of the predictor indicate the $95 \%$ confidence interval and the rug at the bottom the distribution of the data of the inventoried trees. 
(a) TreM richness

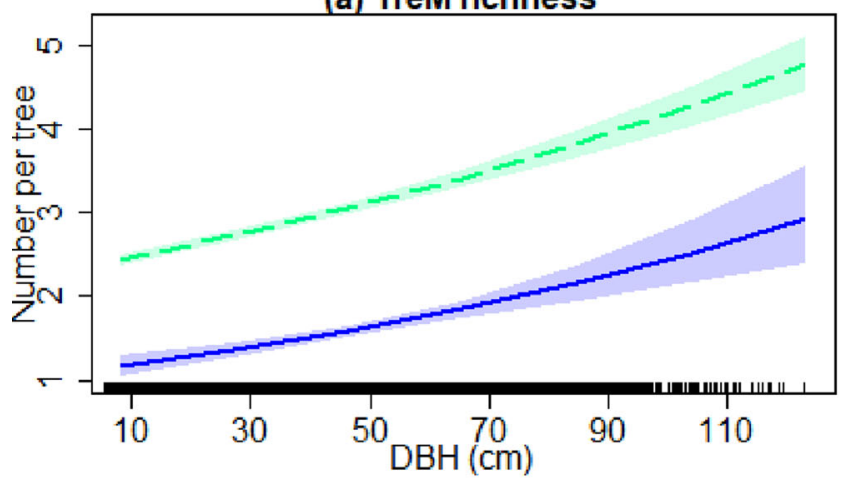

(a) Concavities

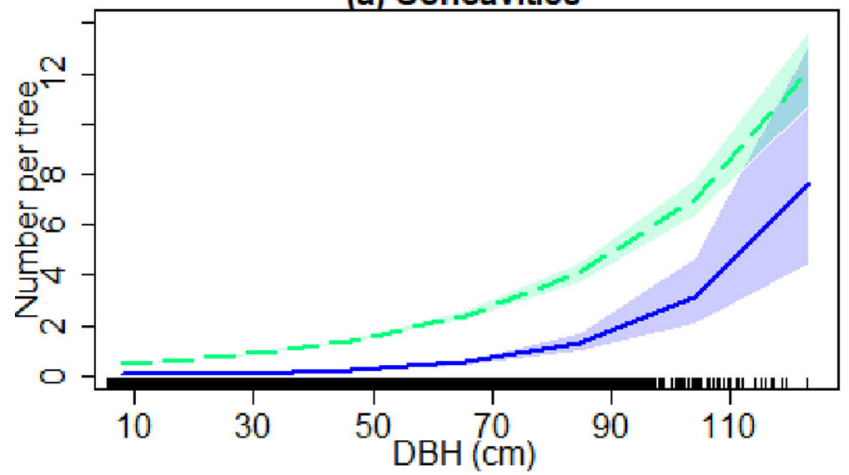

(a) Epiphytes

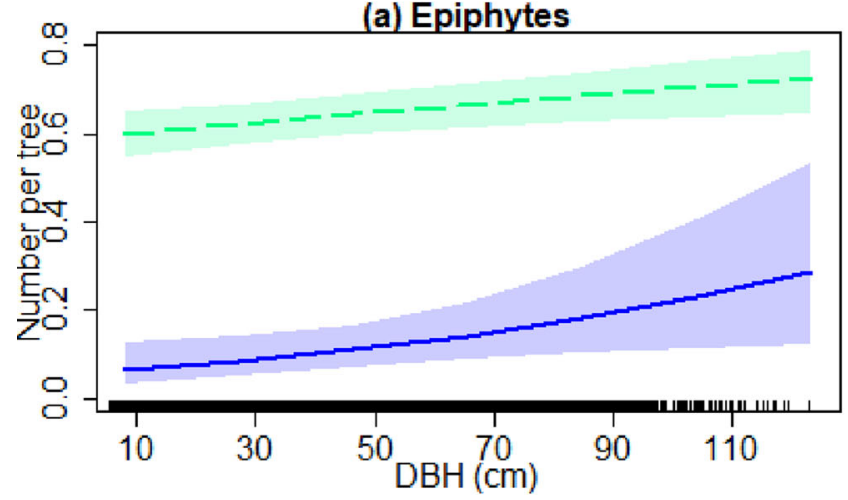

(c) Concavities

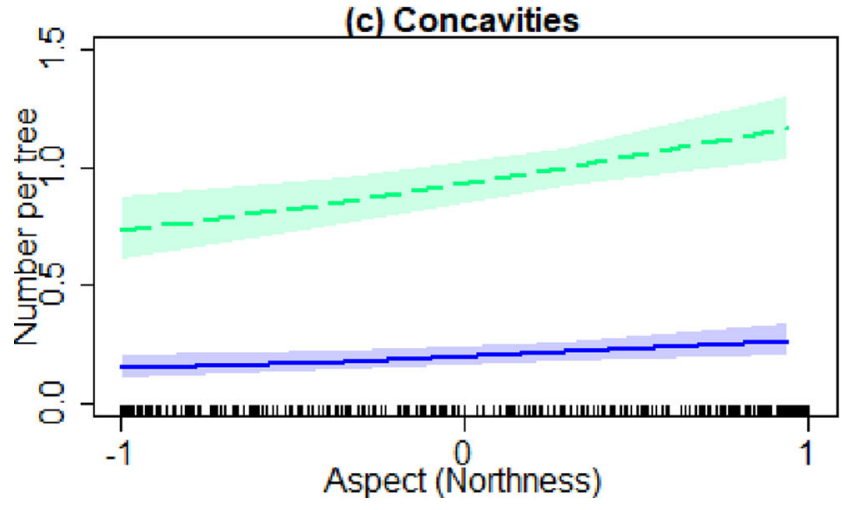

\section{(a) Rot holes}

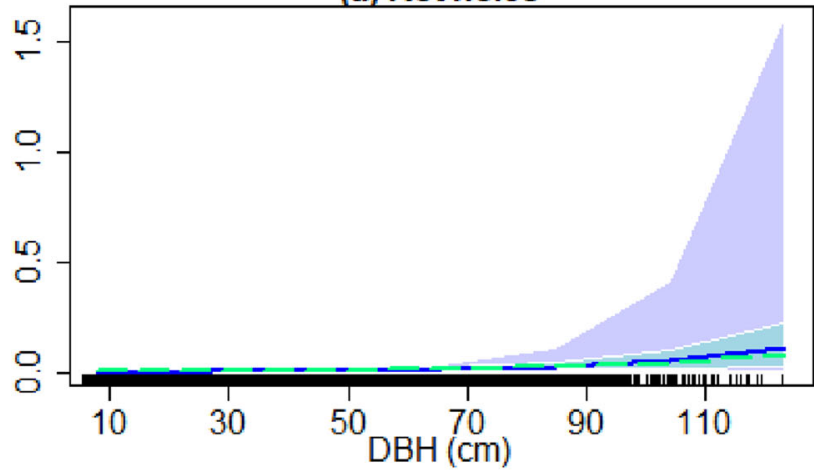

(a) Crown deadwood

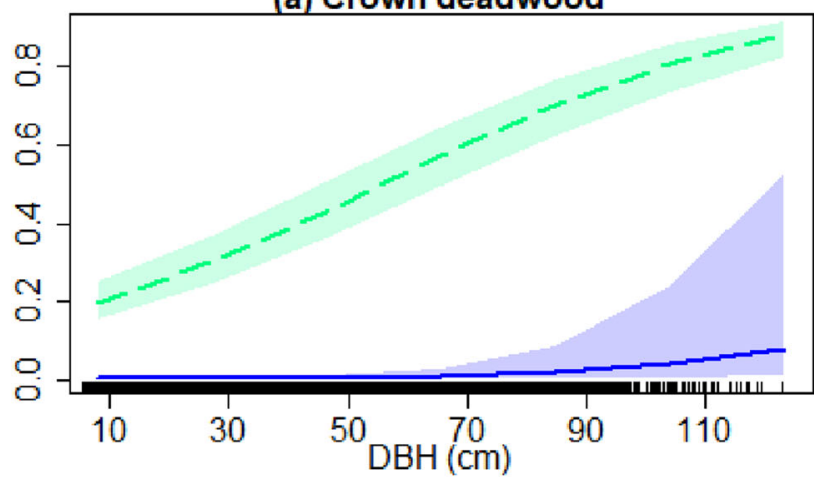

(b) Epiphytes

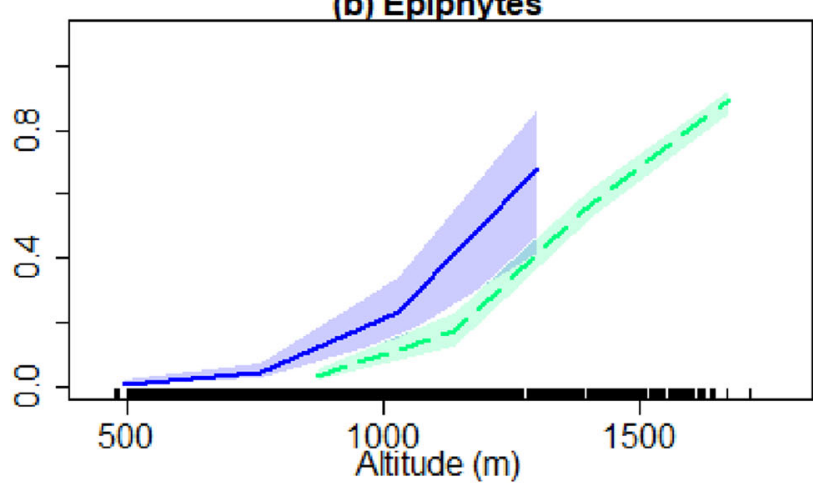

Norway spruce

- - - Primary forests

Managed forests

Figure 3. Effect plots of the significant influence of $\mathbf{a} \mathrm{DBH}, \mathbf{b}$ altitude and $\mathbf{c}$ aspect for overall TreM richness and groups per tree from the generalized linear mixed models of Norway spruce in managed (blue) compared to primary (green) forest sites. The light color bands of the predictor indicate the $95 \%$ confidence interval and the rug at the bottom the distribution of the data of the inventoried trees. 
(a) TreM richness

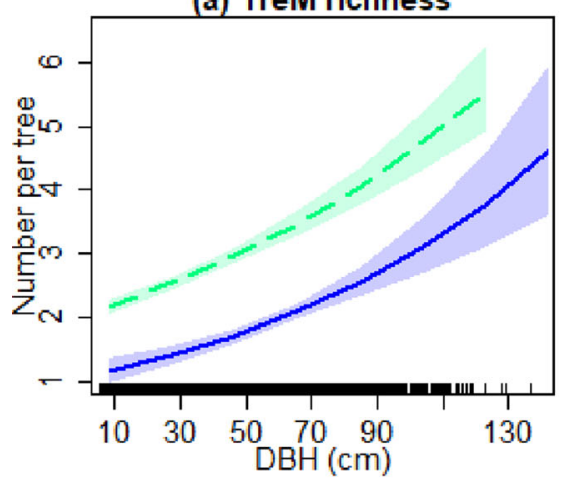

(a) Cankers and burrs

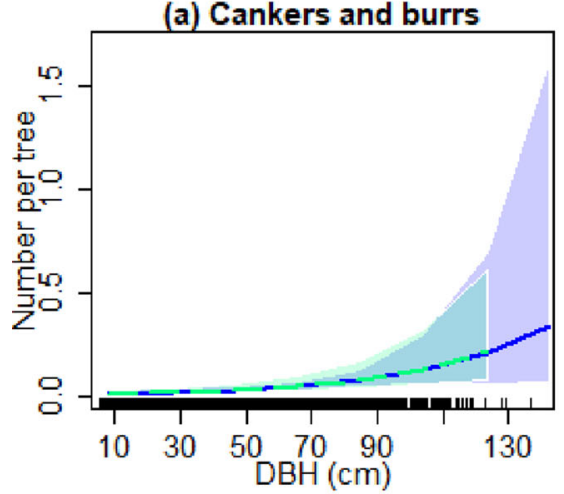

(b) Rot holes

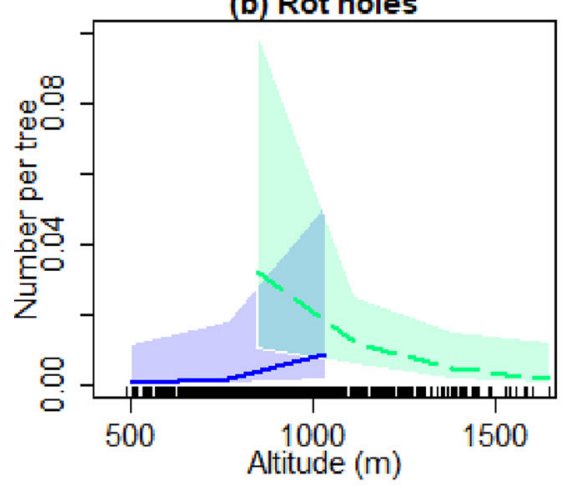

(c) Crown deadwood

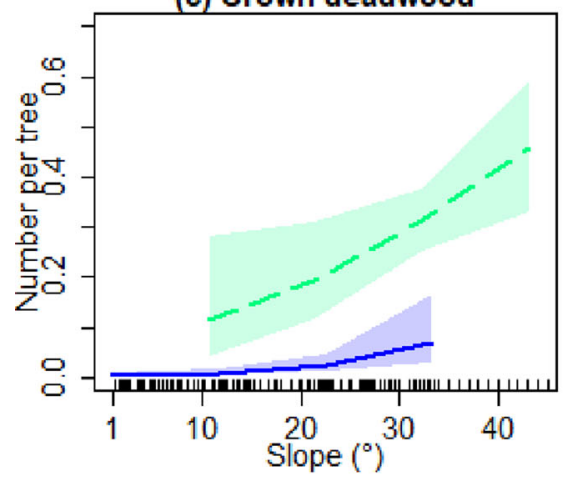

(a) Rot holes

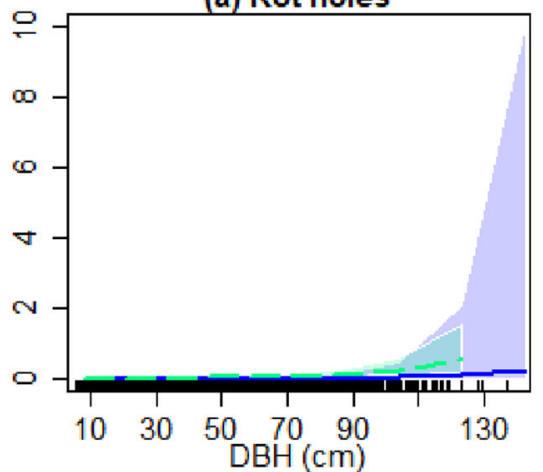

(a) Nests

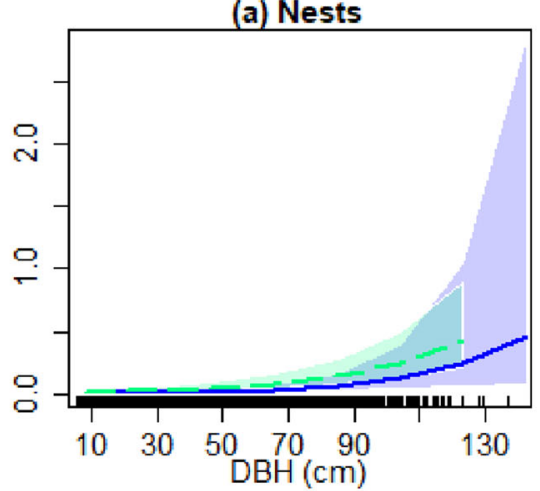

(b) Concavities

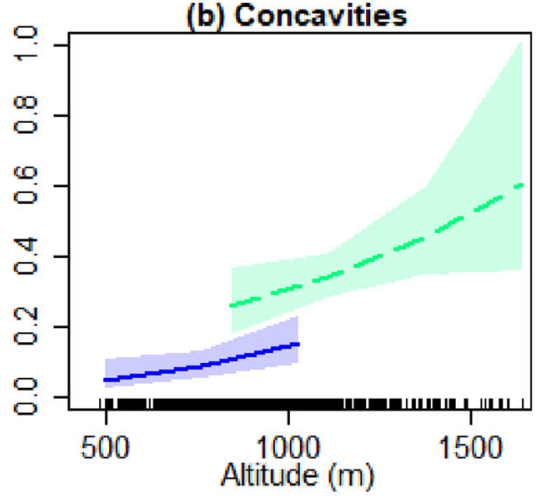

Silver fir (a) Concavities

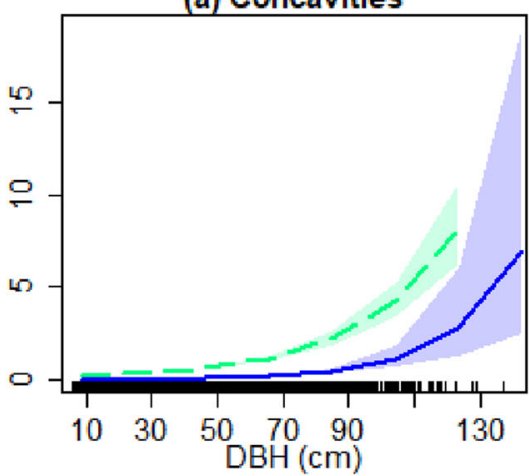

(a) Epiphytes

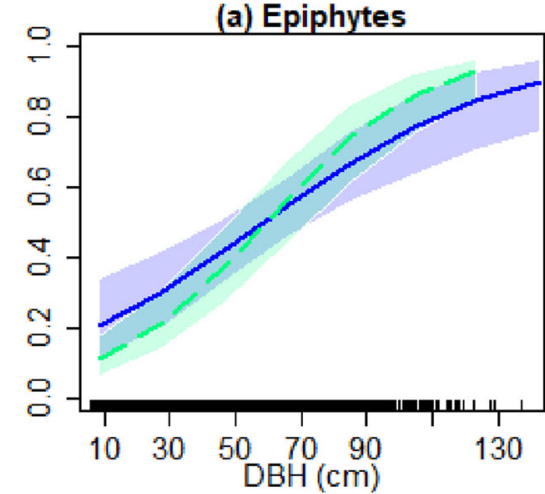

(b) Epiphytes

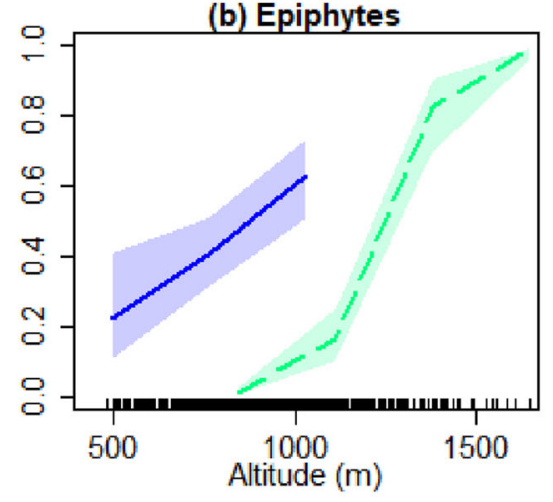

Figure 4. Effect plots of the significant influence of $\mathbf{a} \mathrm{DBH}, \mathbf{b}$ altitude and $\mathbf{c}$ slope for overall TreM richness and groups per tree from the generalized linear mixed models of silver fir in managed (blue) compared to primary (green) forest sites. The light color bands of the predictor indicate the $95 \%$ confidence interval and the rug at the bottom the distribution of the data of the inventoried trees. 


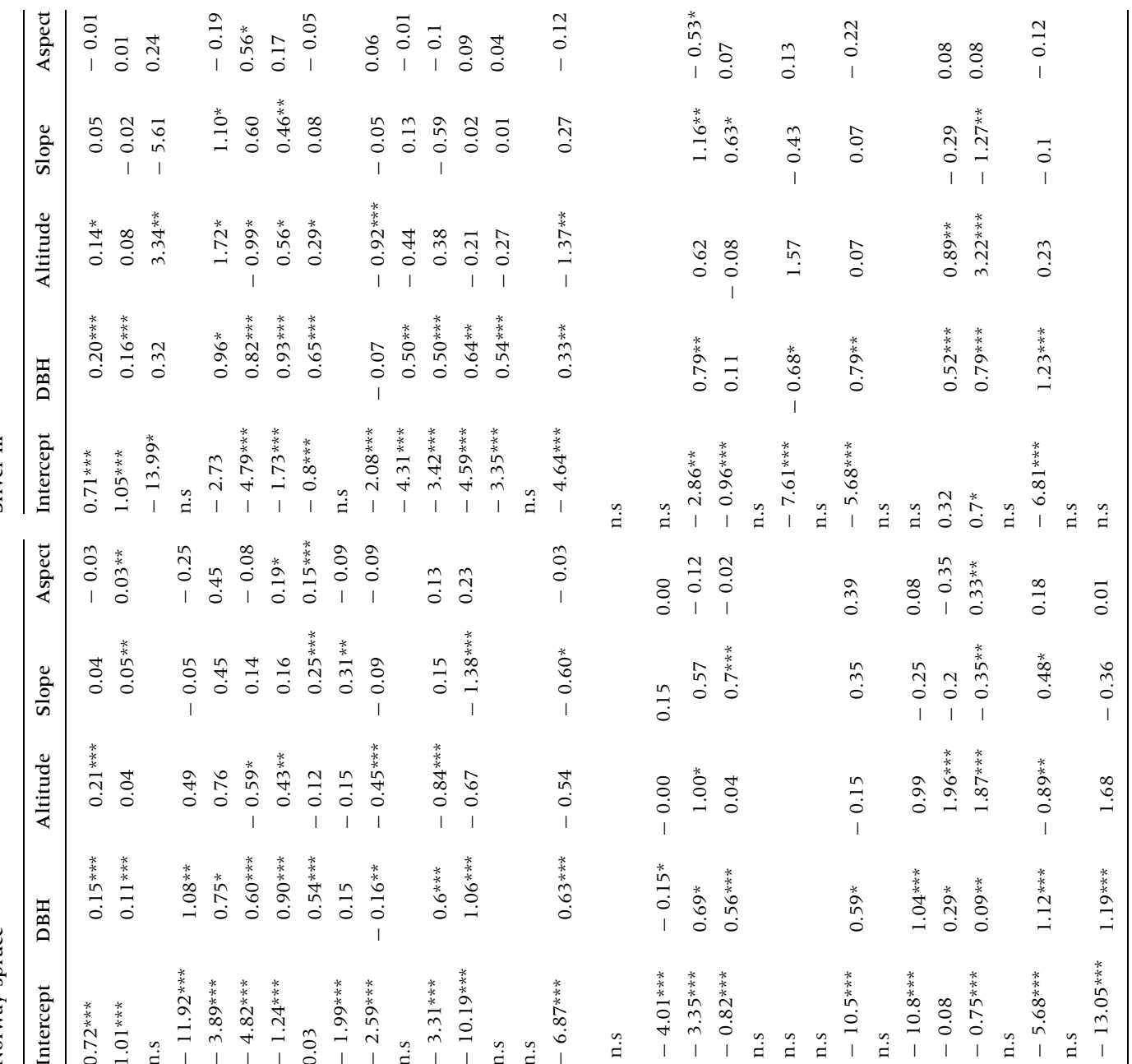

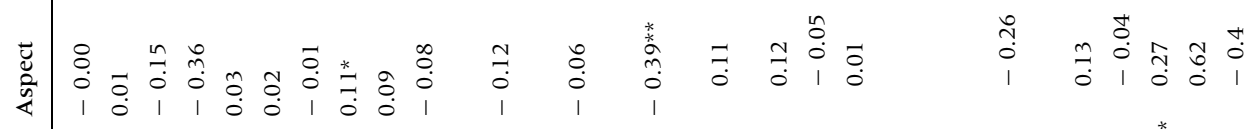

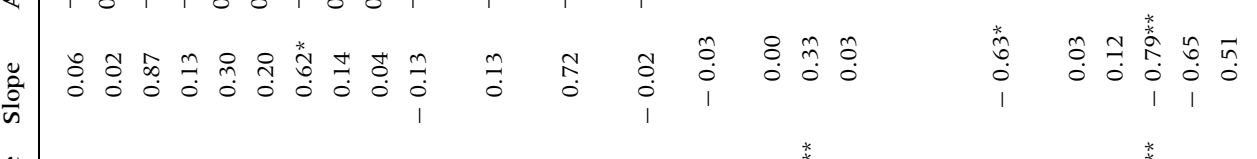

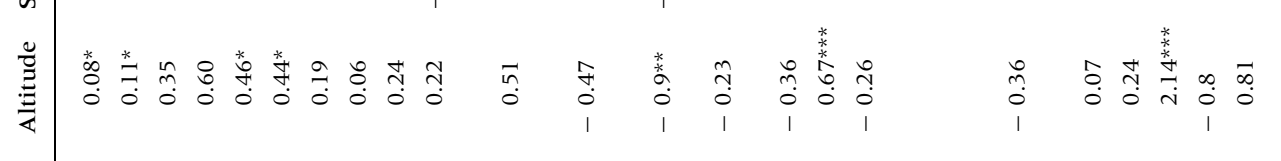

㻤

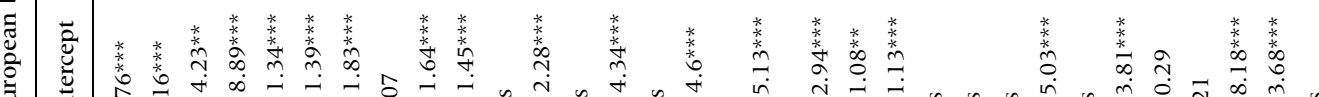

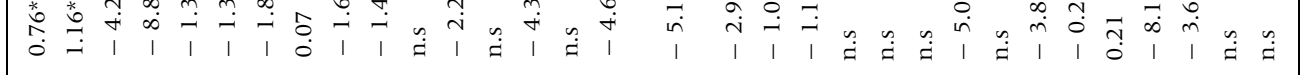

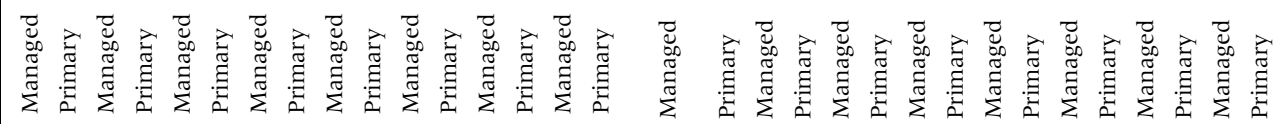


imminent large-scale insect outbreaks that hit the central European region and became more severe recently (Schelhaas and others 2003; Seidl and others 2017). This removal usually targets all trees bearing TreMs that are considered "defects" in forest management (Martin and Raymond 2019).However forest management strategies that aim to tackle this constant removal are provided in the context of retention forestry in CTNFM (Asbeck and others 2020b; Gustafsson and others 2020). These integrative strategies might apply to retaining certain thresholds of deadwood volumes or numbers of habitat trees in managed forests and are increasingly implemented in temperate mountain forests in Europe (Kraus and Krumm 2013; Mölder and others 2020; Thorn and others 2020; Asbeck and others 2021a).

We demonstrated a positive effect of tree diameter on overall TreM richness and a consistent effect across the vast majority of the studied TreM groups. As observed previously, the diameter of the living trees is an important factor influencing the presence of TreMs across tree species, forest types and environmental conditions (Larrieu and $\mathrm{Ca}$ banettes 2012; Kozák and others 2018; Asbeck and others 2019; Paillet and others 2019).

Our results are as well in line with observed patterns of increased TreM numbers in broadleaves (Larrieu and Cabanettes 2012; Regnery and others 2013; Paillet and others 2019), as we found the highest overall TreM richness on European beech. Beech trees can provide up to eight different TreMs compared to less than five in Norway spruce and silver fir of similar dimensions. Interestingly, beech trees seem to host slightly more woodpecker cavities in managed compared to primary forests. This might be related to the fact that woodpeckers are opportunistic in their choice of suitable trees for cavity establishment (Basile and others 2020b), whenever snags are available in lower quantities, which is the case in managed forests compared to primary ones, and they select living trees to excavate their cavities. This is the reason for this result as we included only living trees in the analyses. We observed a higher number of epiphytes in higher elevations both in primary and managed forests. A higher altitude was responsible for an increased diversity of epiphytes (Ding and others 2016), which is possibly due to an increased precipitation or humidity in higher altitudes.

Uncertainties in our results might be caused by the variation in sampling design, as we selected living trees for the TreM survey based on different criteria in managed forests (Asbeck and others 2019), and the primary forest plots (Kozák and others 2018).
However, we included the diameter as predictor in our models and thus took the difference in diameter into account. Our results should be robust concerning this difference in sampling methods since in CTNFM as well as in primary forests, patches of natural regeneration can be spatially close to mature, dominating trees resulting in a relatively wide range of the DBH on small spatial scales (Gustafsson and others 2020). Despite the different time of data collection, we found quite similar results among the drivers of TreMs in managed and primary forests; in future studies, the time of data collection could be further standardized. We also have to point out that we mostly interpreted the models that showed significances in both forest types as these allowed a clearer interpretation compared to cases where only the model for primary or managed forests was significant. The fact that there were many cases in which primary forest models were significant ( 17 out of 96) and managed ones were not ( 2 out of 96) implies that forest management may hinder some of the processes leading to TreM formation and development. On the other hand, nonsignificant results in our models could be grounded in the fact that we had too few observations for the respective TreM groups; for instance, twig tangles were not found in beech or Norway spruce (Table A2).

\section{ConClusion}

We were able to identify that the main drivers of richness and occurrence of TreMs follow similar patterns in managed and primary forests, but that trees in primary forests bear a greater richness of TreMs. Our study suggests that primary forests are essential in providing habitats for forest-dwelling species through a high richness of TreMs. However, many complexes of primary forests are being lost due to poor mapping and lack of protection status (Knorn and others 2013; Mikoláš and others 2019; Sabatini and others 2018, 2020). This allows salvage logging operations, which can lead to extraction of trees with high potential to bear or develop TreMs, representing a threat to the ecosystem itself and the function it fulfills for biodiversity conservation (Thorn and others 2018, 2020). Hence, our results highlight the importance of primary forests for biodiversity conservation but have as well several implications for forest management. First, the constant removal of trees or parts of trees that show "defects," such as exposed sap- and heartwood or crown deadwood created by natural disturbances, needs to be decreased to some extent in managed forests to provide these important TreMs as re- 
sources. This could be implemented by focusing the selection of retention elements such as habitat trees on individuals that provide these obvious and easily identifiable TreMs (Bütler and others 2013; Gustafsson and others 2020). Secondly, an increased provisioning of large-diameter trees as well as beech and other broadleaf species will increase the number of habitats available for forest dwelling species in the studied managed forests. Overall, we recommend forest and nature conservation managers to focus their approaches on: 1) protecting the remaining primary forests and 2) selecting high-quality habitat trees that already provide a high number of microhabitats in managed forests based on the comparison with primary ones.

\section{ACKNOWLEDGEMENTS}

This study was partly funded by the German Research Foundation (DFG), ConFoBi project number GRK 2123. It was as well supported by the institutional project No.CZ.02.1.01/0.0/0.0/16_019/ 0000803 and by the Czech University of Life Sciences (Grant IGA No. A_19_33).

\section{OPEN ACCESS}

This article is licensed under a Creative Commons Attribution 4.0 International License, which permits use, sharing, adaptation, distribution and reproduction in any medium or format, as long as you give appropriate credit to the original author(s) and the source, provide a link to the Creative Commons licence, and indicate if changes were made. The images or other third party material in this article are included in the article's Creative Commons licence, unless indicated otherwise in a credit line to the material. If material is not included in the article's Creative Commons licence and your intended use is not permitted by statutory regulation or exceeds the permitted use, you will need to obtain permission directly from the copyright holder. To view a copy of this licence, visit $h$ ttp://creativecommons.org/licenses/by/4.0/.

\section{FUNDING}

Open Access funding enabled and organized by Projekt DEAL.

\section{DATA AVAILABILITY}

All data used in this article are available and have been published previously in Kozák and others 2018 and Asbeck and others 2019.

\section{REFERENCES}

Asbeck T, Basile M, Stitt J, Bauhus J, Storch I, Vierling KT. 2020a. Tree-related microhabitats are similar in mountain forests of Europe and North America and their occurrence may be explained by tree functional groups. Trees. https://doi. org/10.1007/s00468-020-02017-3.

Asbeck T, Frey J. 2021. Weak relationships of continuous forest management intensity and remotely sensed stand structural complexity in temperate mountain forests. Eur J Forest Res. h ttps://doi.org/10.1007/s10342-021-01361-4.

Asbeck T, Großmann J, Paillet Y, Winiger N, Bauhus J. 2021 a. The use of tree-related microhabitats as forest biodiversity indicators and to guide integrated forest management. Curr Forestry Rep. https://doi.org/10.1007/s40725-020-00132-5.

Asbeck T, Messier C, Bauhus J. 2020b. Retention of tree-related microhabitats is more dependent on selection of habitat trees than their spatial distribution. Eur J Forest Res. https://doi. org/10.1007/s10342-020-01303-6.

Asbeck T, Pyttel P, Frey J, Bauhus J. 2019. Predicting abundance and diversity of tree-related microhabitats in Central European montane forests from common forest attributes. For Ecol Manag 432:400-408.

Asbeck T, Sabatini F, Augustynczik ALD, Basile M, Helbach J, Jonker M, Knuff A, Bauhus J. 2021b. Biodiversity response to forest management intensity, carbon stocks and net primary production in temperate montane forests. Sci Rep 11:1625.

Baguette M, Blanchet S, Legrand D, Stevens VM, Turlure C. 2013. Individual dispersal, landscape connectivity and ecological networks: dispersal, connectivity and networks. Biol Rev 88:310-326.

Basile M, Asbeck T, Jonker M, Knuff AK, Bauhus J, Braunisch V, Mikusiński G, Storch I. 2020a. What do tree-related microhabitats tell us about the abundance of forest-dwelling bats, birds, and insects? J Environ Manage 264:110401.

Basile M, Asbeck T, Pacioni C, Mikusińki G, Storch I. 2020b. Woodpecker cavity establishment in managed forests: relative rather than absolute tree size matters. Wildlife Biology 2020. h ttps://bioone.org/journals/wildlife-biology/volume-2020/is sue-1/wlb.00564/Woodpecker-cavity-establishment-in-mana ged-forests-relative-rather-than/10.2981/wlb.00564.full. Last accessed 19/02/2020

Bauhus J, Puettmann K, Messier C. 2009. Silviculture for oldgrowth attributes. For Ecol Manag 258:525-537.

Bauhus J, Puettmann KJ, Kuehne C. 2013. Close-to-nature forest management in Europe: does it support complexity and adaptability of forest ecosystems? In: Messier C, Puettmann $\mathrm{KJ}$, Coates KD, Eds. Managing forests as complex adaptive systems: building resilience to the challenge of global change, The Earthscan forest library: Routledge. pp 187-213.

Bigler C, Veblen TT. 2009. Increased early growth rates decrease longevities of conifers in subalpine forests. Oikos 118:11301138.

Brang P, Spathelf P, Larsen JB, Bauhus J, Boncina A, Chauvin C, Drossler L, Garcia-Guemes C, Heiri C, Kerr G, Lexer MJ, Mason B, Mohren F, Muhlethaler U, Nocentini S, Svoboda M. 2014. Suitability of close-to-nature silviculture for adapting temperate European forests to climate change. For 87:492503.

Brooks ME, Kristensen K, Van Benthem KJ, Magnusson A, Berg CW, Nielsen A, Skaug HJ, Mächler M, Bolker BM. 2017. glmmTMB balances speed and flexibility among packages for zero-inflated generalized Linear Mixed Modeling. R J 9:378. 
Bruelheide H, Jiménez-Alfaro B, Jandt U, Sabatini FM. 2020. Deriving site-specific species pools from large databases. Ecography:ecog.05172.

Burrascano S, Keeton WS, Sabatini FM, Blasi C. 2013. Commonality and variability in the structural attributes of moist temperate old-growth forests: a global review. For Ecol Manag 291:458-479.

Bütler R, Lachat T, Larrieu L, Paillet Y. 2013. Habitat trees: key elements for forest biodiversity. In: Kraus D, Krumm F, Eds. Integrative approaches as an opportunity for the conservation of forest biodiversity, . European Forest Institute. p 284.

Čada V, Trotsiuk V, Janda P, Mikoláš M, Bače R, Nagel TA, Morrissey RC, Tepley AJ, Vostarek O, Begović K, Chaskovskyy O, Dušátko M, Kameniar O, Kozák D, Lábusová J, Málek J, Meyer P, Pettit JL, Schurman JS, Svobodová K, Synek M, Teodosiu M, Ujházy K, Svoboda M. 2020. Quantifying natural disturbances using a large-scale dendrochronological reconstruction to guide forest management. Ecol Appl 30:eap.2189.

Courbaud B, Pupin C, Letort A, Cabanettes A, Larrieu L. 2017. Modelling the probability of microhabitat formation on trees using cross-sectional data. Börger L, editor. Meth Ecol Evol 8:1347-1359.

Di Filippo A, Biondi F, Maugeri M, Schirone B, Piovesan G. 2012. Bioclimate and growth history affect beech lifespan in the Italian Alps and Apennines. Glob Change Biol 18:960972.

Ding Y, Liu G, Zang R, Zhang J, Lu X, Huang J. 2016. Distribution of vascular epiphytes along a tropical elevational gradient: disentangling abiotic and biotic determinants. Sci Rep 6:19706.

Dormann CF. 2013. Parametrische Statistik. Heidelberg: Springer. https://doi.org/10.1007/978-3-642-34786-3.

Frey J, Asbeck T, Bauhus J. 2020. Predicting tree-related microhabitats by multisensor close-range remote sensing structural parameters for the selection of retention elements. Remote Sens 12:867. https://doi.org/10.3390/rs12050867

Fritz Ö, Heilmann-Clausen J. 2010. Rot holes create key microhabitats for epiphytic lichens and bryophytes on beech (Fagus sylvatica). Biol Conserv 143:1008-1016.

Gustafsson L, Bauhus J, Asbeck T, Augustynczik ALD, Basile M, Frey J, Gutzat F, Hanewinkel M, Helbach J, Jonker M, Knuff A, Messier C, Penner J, Pyttel P, Reif A, Storch F, Winiger N, Winkel G, Yousefpour R, Storch I. 2020. Retention as an integrated biodiversity conservation approach for continuouscover forestry in Europe. AMBIO: J Human Environ 13:8597.

Hanewinkel M, Cullmann DA, Schelhaas M-J, Nabuurs G-J, Zimmermann NE. 2013. Climate change may cause severe loss in the economic value of European forest land. Nature Climate Change 3:203-207.

Hartig F. 2018. Package 'DHARMa'. http://florianhartig.github. io/DHARMa/. https://cran.r-project.org/web/packages/DHAR Ma/DHARMa.pdf. Last accessed 10/07/2017

Jahed RR, Kavousi MR, Farashiani ME, Sagheb-Talebi K, Babanezhad M, Courbaud B, Wirtz R, Müller J, Larrieu L. 2020. A comparison of the formation rates and composition of treerelated microhabitats in beech-dominated primeval carpathian and hyrcanian forests. Forests 11:144. https://doi.org/ $10.3390 /$ f 11020144

Janda P. 2019. Drivers of basal area variation across primary late-successional Picea abies forests of the Carpathian Mountains. For Ecol Manag 9:196-204.
Janda P, Trotsiuk V, Mikoláš M, Bače R, Nagel TA, Seidl R, Seedre M, Morrissey RC, Kucbel S, Jaloviar P, Jasík M, Vysoký J, Šamonil P, Čada V, Mrhalová H, Lábusová J, Nováková MH, Rydval M, Matějů L, Svoboda M. 2017. The historical disturbance regime of mountain Norway spruce forests in the Western Carpathians and its influence on current forest structure and composition. For Ecol Manag 388:67-78.

Johann F, Schaich H. 2016. Land ownership affects diversity and abundance of tree microhabitats in deciduous temperate forests. For Ecol Manag 380:70-81.

Jönsson AM. 2000. Mineral nutrients of beech (Fagus sylvatica) bark in relation to frost sensitivity and soil treatments in southern Sweden. Ann for Sci 57:1-8.

Keeton WS. 2006. Managing for late-successional/old-growth characteristics in northern hardwood-conifer forests. For Ecol Manag 235:129-142.

Knorn J, Kuemmerle T, Radeloff VC, Keeton WS, Gancz V, Biriş I-A, Svoboda M, Griffiths P, Hagatis A, Hostert P. 2013. Continued loss of temperate old-growth forests in the Romanian Carpathians despite an increasing protected area network. Envir Conserv 40:182-193.

Kozák D, Mikoláš M, Svitok M, Bače R, Paillet Y, Larrieu L, Nagel TA, Begovič K, Čada V, Diku A, Frankovič M, Janda P, Kameniar O, Keren S, Kjučukov P, Lábusová J, Langbehn T, Málek J, Mikac S, Morrissey RC, Nováková MH, Schurrman JS, Svobodová K, Synek M, Teodosiu M, Toromani E, Trotsiuk V, Vítková L, Svoboda M. 2018. Profile of tree-related microhabitats in European primary beech-dominated forests. Forest Ecol Manag 429:363-374.

Kraus D, Krumm F. 2013. Integrative approaches as an opportunity for the conservation of forest biodiversity. Bonn: European Forest Institute.

Kulakowski D, Seidl R, Holeksa J, Kuuluvainen T, Nagel TA, Panayotov M, Svoboda M, Thorn S, Vacchiano G, Whitlock C, Wohlgemuth T, Bebi P. 2017. A walk on the wild side: disturbance dynamics and the conservation and management of European mountain forest ecosystems. For Ecol Manag 388:120-131.

Larrieu L, Cabanettes A. 2012. Species, live status, and diameter are important tree features for diversity and abundance of tree microhabitats in subnatural montane beech-fir forests ${ }^{11}$ This article is one of a selection of papers from the International symposium on dynamics and ecological services of deadwood in forest Ecosystems. Can J for Res 42:1433-1445.

Larrieu L, Cabanettes A, Brin A, Bouget C, Deconchat M. 2014. Tree microhabitats at the stand scale in montane beech-fir forests: practical information for taxa conservation in forestry. Eur J for Res 133:355-367.

Larrieu L, Cabanettes A, Delarue A. 2012. Impact of silviculture on dead wood and on the distribution and frequency of tree microhabitats in montane beech-fir forests of the Pyrenees. Eur J for Res 131:773-786.

Larrieu L, Paillet Y, Winter S, Bütler R, Kraus D, Krumm F, Lachat T, Michel AK, Regnery B, Vandekerkhove K. 2018. Tree related microhabitats in temperate and mediterranean european forests: a hierarchical typology for inventory standardization. Ecol Indicat 84:194-207.

Lindenmayer DB, Franklin JF, Fischer J. 2006. General management principles and a checklist of strategies to guide forest biodiversity conservation. Biol Conserv 131:433-445.

Lüdecke D. 2018. ggeffects: tidy data frames of marginal effects from regression models. JOSS 3:772. 
Martin M, Fenton NJ, Morin H. 2021. Tree-related microhabitats and deadwood dynamics form a diverse and constantly changing mosaic of habitats in boreal old-growth forests. Ecol Indicat 128:107813.

Martin M, Raymond P. 2019. Assessing tree-related microhabitat retention according to a harvest gradient using tree-defect surveys as proxies in Eastern Canadian mixedwood forests. For Chronicle 95:157-170.

Messier C, Bauhus J, Doyon F, Maure F, Sousa-Silva R, Nolet P, Mina M, Aquilué N, Fortin M-J, Puettmann K. 2019. The functional complex network approach to foster forest resilience to global changes. For Ecosyst 6:21.

Mikoláš M, Ujházy K, Jasík M, Wiezik M, Gallay I, Polák P, Vysoký J, Čiliak M, Meigs GW, Svoboda M. 2019. Primary forest distribution and representation in a Central European landscape: results of a large-scale field-based census. For Ecol Manag 449:117466.

Mölder A, Schmidt M, Plieninger T, Meyer P. 2020. Habitat-tree protection concepts over 200 years. Conserv Biol. https://doi. org/10.1111/cobi.13511.

Nagel TA, Svoboda M, Kobal M. 2014. Disturbance, life history traits, and dynamics in an old-growth forest landscape of southeastern Europe. Ecol Appl 24:663-679.

Paillet Y, Archaux F, Boulanger V, Debaive N, Fuhr M, Gilg O, Gosselin F, Guilbert E. 2017. Snags and large trees drive higher tree microhabitat densities in strict forest reserves. For Ecolo Manag 389:176-186.

Paillet Y, Archaux F, du Puy S, Bouget C, Boulanger V, Debaive N, Gilg O, Gosselin F, Guilbert E. 2018. The indicator side of tree microhabitats: a multi-taxon approach based on bats, birds and saproxylic beetles. J Appl Ecol 55:2147-2159.

Paillet Y, BergèS L, HjäLtéN J, oDor P, Avon C, BernhardtRöMermann M, Bijlsma RJ, De Bruyn L, Fuhr M, GrandinKanka UR, Lundin L, Luque S, Magura T, Matesanz S, MéSzáRos I, Sebastià MT, Schmidt W, StandováR T, TóThméRéSz B, Uotila A, Valladares F, VellakVirtanen KR. 2010. Biodiversity differences between managed and unmanaged forests: metaanalysis of species richness in europe. Conserv Biol 24:101-1 12.

Paillet Y, Coutadeur P, Vuidot A, Archaux F, Gosselin F. 2015a. Strong observer effect on tree microhabitats inventories: a case study in a French lowland forest. Ecological Indicators 49:14-23.

Paillet Y, Debaive N, Archaux F, Cateau E, Gilg O, Guilbert E. 2019. Nothing else matters? Tree diameter and living status have more effects than biogeoclimatic context on microhabitat number and occurrence: an analysis in French forest reserves. PLOS ONE 14:e0216500.

Paillet Y, Pernot C, Boulanger V, Debaive N, Fuhr M, Gilg O, Gosselin F. 2015b. Quantifying the recovery of old-growth attributes in forest reserves: a first reference for France. For Ecol Manag 346:51-64.

Pettit JL, Pettit JM, Janda P, Rydval M, Čada V, Schurman JS, Nagel TA, Bače R, Saulnier M, Hofmeister J, Matula R, Kozák D, Frankovič M, Turcu DO, Mikoláš M, Svoboda M. 2021. Both Cyclone-induced and Convective Storms Drive Disturbance Patterns in European Primary Beech Forests. Geophys Res Atmos 126. https://onlinelibrary.wiley.com/doi/10.1029/ 2020JD033929. Last accessed 21/06/2021

Puverel C, Abourachid A, Böhmer C, Leban J-M, Svoboda M, Paillet Y. 2019. This is my spot: What are the characteristics of the trees excavated by the Black Woodpecker? A case study in two managed French forests. Forest Ecology and Management 453:117621.
R Core Team. 2016. R: A language and environment for statistical computing. R Foundation for Statistical Computing, Vienna, Austria. https://www.R-project.org/

Regnery B, Paillet Y, Couvet D, Kerbiriou C. 2013. Which factors influence the occurrence and density of tree microhabitats in Mediterranean oak forests? For Ecol Manag 295:1 18-125.

Sabatini FM, Burrascano S, Keeton WS, Levers C, Lindner M, Pötzschner F, Verkerk PJ, Bauhus J, Buchwald E, Chaskovsky O, Debaive N, Horváth F, Garbarino M, Grigoriadis N, Lombardi F, Marques Duarte I, Meyer P, Midteng R, Mikac S, Mikoláš M, Motta R, Mozgeris G, Nunes L, Panayotov M, Ódor P, Ruete A, Simovski B, Stillhard J, Svoboda M, Szwagrzyk J, Tikkanen O-P, Volosyanchuk R, Vrska T, Zlatanov T, Kuemmerle T. 2018. Where are Europe's last primary forests? Divers Distrib 24:1426-1439.

Sabatini FM, Keeton WS, Lindner M, Svoboda M, Verkerk PJ, Bauhus J, Bruelheide H, Burrascano S, Debaive N, Duarte I, Garbarino M, Grigoriadis N, Lombardi F, Mikoláš M, Meyer P, Motta R, Mozgeris G, Nunes L, Ódor P, Panayotov M, Ruete A, Simovski B, Stillhard J, Svensson J, Szwagrzyk J, Tikkanen OP, Vandekerkhove K, Volosyanchuk R, Vrska T, Zlatanov T, Kuemmerle T. 2020. Protection gaps and restoration opportunities for primary forests in Europe. Divers. Distrib 26:16461662.

Schall P, Gossner MM, Heinrichs S, Fischer M, Boch S, Prati D, Jung K, Baumgartner V, Blaser S, Böhm S, Buscot F, Daniel R, Goldmann K, Kaiser K, Kahl T, Lange M, Müller J, Overmann J, Renner SC, Schulze E-D, Sikorski J, Tschapka M, Türke M, Weisser WW, Wemheuer B, Wubet T, Ammer C. 2018. The impact of even-aged and uneven-aged forest management on regional biodiversity of multiple taxa in European beech forests. J Appl Ecol 55:267-278.

Schall P, Heinrichs S, Ammer C, Ayasse M, Boch S, Buscot F, Fischer M, Goldmann K, Overmann J, Schulze E, Sikorski J, Weisser WW, Wubet T, Gossner MM. 2020. Can multi-taxa diversity in European beech forest landscapes be increased by combining different management systems? J Appl Ecol 57:1365-1375.

Schelhaas M-J, Nabuurs G-J, Schuck A. 2003. Natural disturbances in the European forests in the 19th and 20th centuries. Global Change Biol 9:1620-1633.

Seidl R, Schelhaas M-J, Rammer W, Verkerk PJ. 2014. Increasing forest disturbances in Europe and their impact on carbon storage. Nature Clim Change 4:806-810.

Seidl R, Thom D, Kautz M, Martin-Benito D, Peltoniemi M, Vacchiano G, Wild J, Ascoli D, Petr M, Honkaniemi J, Lexer MJ, Trotsiuk V, Mairota P, Svoboda M, Fabrika M, Nagel TA, Reyer CPO. 2017. Forest disturbances under climate change. Nature Clim Change 7:395-402.

Spînu AP, Petritan IC, Mikoláš M, Janda P, Vostarek O, Čada V, Svoboda M. 2020. Moderate- to high-severity disturbances shaped the structure of primary picea abies (L.) Karst. For Southern Carpathians. Forests 11:1315.

Storch F, Dormann CF, Bauhus J. 2018. Quantifying forest structural diversity based on large-scale inventory data: a new approach to support biodiversity monitoring. For Ecosyst 5:34.

Storch I, Penner J, Asbeck T, Basile M, Bauhus J, Braunisch V, Dormann CF, Frey J, Gärtner S, Hanewinkel M, Koch B, Klein A, Kuss T, Pregernig M, Pyttel P, Reif A, Scherer-Lorenzen M, Segelbacher G, Schraml U, Staab M, Winkel G, Yousefpour R. 2020. Evaluating the effectiveness of retention forestry to enhance biodiversity in production forests of Central Europe 
using an interdisciplinary, multi-scale approach. Ecol Evol ece3.6003:1489-1509.

Svoboda M, Janda P, Bače R, Fraver S, Nagel TA, Rejzek J, Mikoláš M, Douda J, Boublík K, Šamonil P, Čada V, Trotsiuk V, Teodosiu M, Bouriaud O, Biriş AI, Sýkora O, Uzel P, Zelenka J, Sedlák V, Lehejček J. 2014. Landscape-level variability in historical disturbance in primary Picea abies mountain forests of the Eastern Carpathians, Romania. J Veg Sci 25:386-401

Thom D, Golivets M, Edling L, Meigs GW, Gourevitch JD, Sonter LJ, Galford GL, Keeton WS. 2019. The climate sensitivity of carbon, timber, and species richness co-varies with forest age in boreal-temperate North America. Glob Change Biol gcb.14656:2446-2458.

Thorn S, Bässler C, Brandl R, Burton PJ, Cahall R, Campbell JL, Castro J, Choi C-Y, Cobb T, Donato DC, Durska E, Fontaine JB, Gauthier S, Hebert C, Hothorn T, Hutto RL, Lee E-J, Leverkus AB, Lindenmayer DB, Obrist MK, Rost J, Seibold S, Seidl R, Thom D, Waldron K, Wermelinger B, Winter M-B, Zmihorski M, Müller J. 2018. Impacts of salvage logging on biodiversity: a meta-analysis. Struebig M, editor. J Appl Ecol 55:279-289.

Thorn S, Chao A, Georgiev KB, Müller J, Bässler C, Campbell JL, Castro J, Chen Y-H, Choi C-Y, Cobb TP, Donato DC, Durska E,
Macdonald E, Feldhaar H, Fontaine JB, Fornwalt PJ, Hernández RMH, Hutto RL, Koivula M, Lee E-J, Lindenmayer D, Mikusiński G, Obrist MK, Perlík M, Rost J, Waldron K, Wermelinger B, Weiß I, Żmihorski M, Leverkus AB. 2020. Estimating retention benchmarks for salvage logging to protect biodiversity. Nat Commun 11:4762.

Vuidot A, Paillet Y, Archaux F, Gosselin F. 2011. Influence of tree characteristics and forest management on tree microhabitats. Biol Conserv 144:441-450.

Weinacker H, Koch B, Weinacker R. 2004. TREESVIS: a software system for simultaneous ED-real-time visualisation of DTM, DSM, laser raw data, multispectral data, simple tree and building models. Int Archives Photogrammet Remote Sens Spat Inf Sci 36:90-95.

Wirth C, Messier C, Bergeron Y, Frank D, Fankhänel A. 2009. Old-Growth forest definitions: a pragmatic view. In: Wirth C, Gleixner G, Heimann M. Eds. Old-Growth forests. Ecological studies (analysis and synthesis), vol 207. Springer, Berlin, Heidelberg. https://doi.org/10.1007/978-3-540-92706-8_2.

Zuur AF, Ieno EN, Elphick CS. 2010. A protocol for data exploration to avoid common statistical problems: data exploration. Methods Ecol Evolut 1:3-14. 